\title{
FORME I FORMALNOSTI KOD HARTIJA OD VREDNOSTI
}

\author{
Predrag Jovićević \\ Fakultet za primenjeni menadžment, ekonomiju i finansije, Beograd \\ Slobodan Andžić \\ Beogradska poslovna škola \\ Ana Koprivica \\ Visoka škola za menadžment i ekonomiju, Kragujevac
}

edan ograničeni pregled instituta forme i formalnostima sličnih formi
u ugovornom pravu, samo su polazne premise koje nam mogu pomoći da se orijentišemo u problematici forme kod hartija od vrednosti. Naime, ne može biti ikakve sumnje o strogoj formalnosti kod jednostrane izjave volje one strane koja se želi obavezati kao emitent hartija od vrednosti.

Ovde ne može biti ikakve zabune kod činjenice što se ovde ne radi o izjavi volje dve strane, kao što je to slučaj kada je u pitanju ugovor i da se na hartiji od vrednosti nalazi kao jedan od bitnih elemenata formalnog samo potpis obavezujuće strane, emitenta.

Ključne reči: hartije od vrednosti, forma, tržišta

Uvod

osadašnja saznanja o formi mogu, ali i ne moraju biti dovoljna da bi se potreba za odgovarajućom formom kod hartija od vrednosti, mogla objasniti. Koji bi se ciljevi i interesi mogli identifikovati pri propisivanju bitne forme kod hartija od vrednosti, moguće je utvrditi razmatranjem ne samo fenomenologije forme već i institutima koje zakonodavac uvodi sličnim pojavnim oblikom za spoljnu manifestaciju izjava volje iz određenih razloga ali, izostanak takve spoljne manifestacije volje redovno ne uslovljava nastanak pravnog posla, već predviđa druge sankcije. Razmatranje ovih formalnosti, koje nazivamo uslovno formalnostima sličnim formi, može ali i ne mora da bude značajno za pitanje promene sadašnjeg dominantnog pojavnog oblika hartija od vrednosti.

Ipak, emitovanje hartija od vrednosti predstavlja značajan društveno - ekonomski događaj kako u okviru poslovanja nekog pravnog lica tako i u okvirima jedne države zajednice u sprovođenju njene ekonomske politike. Razume se da ovde ne možemo ostaviti po strani ukupnost zainteresovanosti i mogućnosti pojedinaca koji svoja (trenutno ili na duže vreme), slobodna sredstva plasira u hartije od vrednosti. Odatle i povećani interes države da pravnim sredstvima i van nametnute bitne forme i uslova koji prate obaveznu sadržinu odnosa iz hartije od vrednosti, reguliše i postupak oko izdavanja takvih hartija, odnosno da propiše ne samo šta isprava (ili njima dematerijalizovana forma) treba da sadrži, već i da u meri kojom to smatra nužnim, propiše postupak i uslove za emisiju. Te i takve uslove ovde, gde govorimo o bitnoj formi hartija od vrednosti i transformacije te for- 
me u njen dematerijalizovani vid, ne možemo nabrojati jer bi to prevazišlo okvire ove teme naročito $s$ toga što te intervencije države mogu biti različite za pojedine hartije i promenljive kako u vremenu tako i u odnosu na vrstu emitenta. Predmet ovog rada je najpre da razdvojimo takve formalnosti od bitne forme, a zatim, da kroz njihov pojedinačni prikaz ukažemo na eventualnu vezu takvog instituta sa hartijama od vrednosti u obliku isprave ili njenog dematerijalizovanog vida. Posebno kada formalnost slična formi može da predstavlja uslov za emisiju, pa čak, uz bitnu formu, i postojanje hartija od vrednosti. ${ }^{1}$

\section{Formalnosti fiskalne politike}

Propisi o porezima i doprinosima, često traže da, kod akata izražavanja saglasnosti volja, koja dovode do ugovora ili onih pravnih veza stvorenih jednostranom izjavom volje, kao predmeta u prometu imovinskih vrednosti, ti akti budu sastavljeni u pismenom obliku kao pogodnom za intervenciju fiskalnih organa. Pri tome se mora imati u vidu da se radi o obavezi ne između strana ugovornica, već o njihovoj zajedničkoj ili pojedinačnoj obavezi prema takvom fiskalnom, kao upravnom organu. To znači da formalnost, nametnuta fiskalnim potrebama, nije forma koja uslovljava valjanost pravnog posla ${ }^{2}$, već naprotiv, on je posledica imovinskopravnog prometa provedenog navedenim aktima, tj. ugovorom ili jednostranom izjavom volje. Ugovor, o na primer prodaji neke pokretne stvari, važi bez obzira da li je ugovor sačinjen u pismenom obliku ili običnim konsenzusom. Kada ovaj ugovor ne bi bio valjan iz bilo kojih razloga, ne bi naravno postojala ni fiskalna obaveza za odgovarajući promet kojeg, u takvom slučaju, ne bi ni bilo. Drugim rečima, zahtev za postojanjem u pismenom obliku postignutih saglasnosti koje sačinjavaju ugovor (ili jednostrana izjava volje), za potrebe fiskusa, jeste formalnost koja ne spada u oblast građanskog, već upravnog prava, koji ne dira u postojeći građanskopravni odnos, ali služi potrebama upravnih vlasti, koje prvenstveno radi uvida u sam predmet prometa i visinu cene, obezbeđuju javne prihode nametanjem fiskalnih obaveza provedenom prometu građanskopravnim putem.

U kojoj meri se postojeća obavezna forma hartija od vrednosti podređuje formalnosti fiskalnih potreba? Drugačije formulisano, ovo pitanje se postavlja u vidu hipoteze po kojoj bi napuštanje važeće pismene forme hartija od vrednosti, bilo irelevantno za formalnosti fiskalnih potreba.

Fiskus bez sumnje može da ima uticaja na to da se sav, ili najveći deo prometa sredstava podvrgne, ne samo njegovoj kontroli već i svrsi za koju je prvenstveno zainteresovan, a to je ubiranje prihoda ${ }^{3}$ u prometu novčanih sredstava, pa i kada se ona prenose putem plasmana u hartije od vrednosti. Ostavljajući po strani potrebe i mogućnosti fiskalnog orga-

\footnotetext{
${ }^{1}$ Formalnost (novolatinski "formalitas") - može da znači uobičajenost, utvrđene običaje postupanja po izvesnom redu i propisima, (tek) koliko da se učini. Ne treba mešati ovaj izraz sa "formalizmom“ koji znači: 1) preterano polaganje na spoljašnosti (forma) - tj. pretpostavljanje oblika sadržini i suštini: 2) preteranost u čuvanju ustaljene forme u nekom radu na štetu suštine stvari; 3) bukvalno shvatanje propisa i nevođenje računa o njihovom cilju i njihovoj suštini.

${ }^{2}$ Perović S., Formalni ugovori u građanskom pravu, Beograd, 1964. str. 63.

${ }^{3}$ Radosavljević, M. [2018]. Javni dug sa aspekta finansiranja Vojske Srbije. Oditor - časopis za Menadžment, finansije i pravo, 4(2), 48-57.
} 
na da li će ili neće ubirati prihode od ovakvog prometa, i da li bi zamena pismene isprave kao pojavnog oblika hartije od vrednosti u neki drugi pojavni oblik, pa i dematerijalizaciju, uticala na mogućnost izbegavanja fiskalnih obaveza, ostaje otvoreno, kao faktičko pitanje koje opravdava ili ne opravdava insistiranje na pismenoj formi takvih hartija.

Međutim, ako bi u ovom pitanju priznali dominantnu ulogu fiskalnih potreba u odlučivanju obavezne forme hartija od vrednosti, tada bi morali revidirati i dominantno načelo konsenzusa u oblasti čitavog građanskog prava, budući da bi se isti efekti fiskalne evazije mogli manifestovati dominacijom ovog načela u svim oblastima pravnog prometa. ${ }^{4}$ Prema tome, teško bi se mogli braniti argumenti koji bi išli na to da, formalnosti fiskalnih potreba zahtevaju, u domenu hartija od vrednosti, formu pismene isprave, a da iz tih istih potreba isključimo promet koji bi se obavljao na osnovu neformalnih pravnih poslova. Razume se da takav uticaj ne možemo potpuno negirati, ali njegova dosledna primena bi bila neracionalna i kontraproduktivna pa, u stvarnosti, u našim uslovima ne možemo ga prihvatiti kao relevantan faktor ni u domenu hartija od vrednosti. Ovo naročito stoga što upravo na koncipiranom sistemu nematerijalizovani pojavni oblik hartija od vrednosti, na odgovarajući način, može obezbediti uslove koji fiskusu efikasno omogućavaju obavljanje njegovih funkcija.

\section{Overa isprave}

Overa, pre svega treba da predstavlja radnju nadležnog službenog organa ${ }^{5}$, koji u oblasti ugovornog prava, treba da potvrdi autentičnosti potpisa jedne ili obe ugovorne strane. Ova se definicija može shodno primeniti i na sve izvore obligacija koje nastaju jednostranom izjavom volje, pa prema tome i hartije od vrednosti.

Treba odmah napomenuti da overa isprave ${ }^{6}$ može da bude kako deo obavezne forme za punovažnost ugovora, tako i radnju koja nema uticaja na nastanak pravnog posla. Prema tome, overa može biti uključena u pojam bitne forme, kada predstavlja njen relevantni deo, a može biti samo formalnost nametnuta učesnicama posla iz drugih razloga.

Ovde se nećemo upuštati u razmatranja onih slučajeva koji se odnose na overu kao dela obavezne forme akata , jer je to tema koja se uključuje u deo razmatranja o obaveznosti forme u svim njenim vidovima (dakle ne samo kao na primer pismenost isprave, već kao dodatni formalni zahtev), već samo o overi kao formalnosti sličnoj formi od koje ne zavisi valjanost pravnog posla, sa posebnim osvrtom na (ne)postojanje ove overe kod hartija od vrednosti.

Potreba za autorizacijom isprave u smislu overe izlazi iz konteksta građanskog prava i obično je nalazimo kao ustanovu u porodičnom, naslednom, upravnom i dr. radi, različitih svrha - dokaznih, evidencionih, zaštite od brzopletih odluka, nerazumevanja posledica izjavljene volje i slično. Imperativna norma upućuje na obaveznu formu, na primer u obliku pismene isprave, trebalo bi, za valjanost akta da on bude potpisan od strane lica

\footnotetext{
${ }^{4}$ Krstić, S. L., Gligić-Savić, A. P., \& Gligić-Dumonjić, J. P. [2017]. Mogućnost upravljanja rizikom portfolija hartija od vrednosti. Vojno delo, 69(6), 374-383.

${ }^{5}$ Salma, J. [2012]. Notarijalno obligaciono pravo - načela javno-beležničkog prava, javno-beležnička forma i odgovornost javnih beležnika prema pravu Republike Srbije. Zbornik radova Pravnog fakulteta, Novi Sad, 46(1), 87-100.

${ }^{6}$ Dovoljno je ovde podsetiti na (jednostranu) izjavu poslednje volje (testamenta) u naslednom pravu kao izrazito strogo formalnom aktu čija punovažnost zavisi od ispunjavanja propisane forme od strane zakona (zakonska).

${ }^{7}$ Đukić, A. [2017]. Krađa identiteta - oblici, karakteristike i rasprostranjenost. Vojno delo, 69(3), 99-118.
} 
koje se tim aktom obavezuje. ${ }^{8} \mathrm{Ne}$ bi bilo u načelu prihvatljivo da takvi potpisi budu još i overavani od strane nadležnog lica, budući da time pravni posao ne dobija ništa više u materijalnopravnom smislu od onog što je sadržina volje stranaka, bilo da je pravni posao, odnosno potpis obavezujućih strana, overen ili ne.

Sa stanovišta jednostrane izjave volje i hartija od vrednosti, razmatranja overe ne bi trebalo da budu sporna. Istina, obaveznost forme kod hartija od vrednosti kao pismenih isprava, na kojima se uvek, kao bitan sastojak takve hartije mora naći i potpis izdavaoca, ne traži nikakav dodatni formalizam sličan formi u obliku overe, ali i kada bi takav uslov postojao, bio bi bez sumnje besmislen jer bi praktično onemogućio brz promet hartija od vrednosti. Štaviše, kod hartija od vrednosti izdatih u seriji, potpis se izdavaoca može zameniti njegovim faksimilom, ${ }^{9}$ dok se u ostalom, ugovornom pravu ova olakšica prepušta poslovnom običaju.

Kod hartija od vrednosti ne traži se odgovarajuća radnja organa koji bi bio dužan da overi autentičnost potpisa izdavaoca hartije od vrednosti, što je u smislu izloženog sasvim logično i razložno.

Postupak overe nikako ne treba mešati sa postupkom davanja odobrenja od strane nadležnog organa kod emisije dugoročnih hartija od vrednosti, o čemu će ovde biti posebno reči kao formalnosti sličnoj formi, ali sa specifičnim karakteristikama upravnog postupka i akta donetog u takvom postupku u obliku odobrenja za emisiju takvih hartija.

\section{Odobrenje kao formalnost slična formi}

Kod razmatranja pravne prirode odobrenja, što smatramo nužnim kada se radi o primeni ovog instituta kod hartija od vrednosti, naićićemo na neke sporne teorijske pristupe. Kod emisije dugoročnih hartija od vrednosti institut posebnog državnog organa koji nadzor nad poslovanjem hartija od vrednosti vrši između ostalog i davanjem odobrenja za izdavanje ovih hartija kao i za rad berze i berzanskih posrednika u Srbiji. Stoga je značajno raspraviti pravnu prirodu ovog odobrenja služeći se, pri tome objašnjenjima koja institut odobrenja vidi u oblasti ugovornih odnosa, odnosno upravnog prava.

Pravna priroda saglasnosti u ugovornom pravu, polazi od shvatanja koje ovaj institut svrstava u obaveznu formu kod izjave volje, pa preko shvatanja da se radi o odloženom uslovu i najzad, da se radi o manjkavosti volje koja tek davanjem saglasnosti dobija svoju relevantnu dimenziju. ${ }^{10}$

Gledište po kojem bi saglasnost za zaključenje ugovora bila sastavni deo forme, a ne formalnost koja sliči formi, polazi od toga da saglasnost predstavlja zakonski uslov punovažnosti nekih ugovora - dakle, deo forme kojom se volja kao neophodan uslov za sklapanje ugovora izražava. Jednom rečju, prema ovom stanovištu, odobrenje se ima smatrati kao nerazdvojan deo obavezne forme, bez kojeg ugovora nema.

Primenjeno na jednostranu izjavu volje, sigurni smo da se u ovakvom stanovištu ništa ne može izmeniti, jer ako u ugovornom pravu obaveznost forme postoji bilo za jednu ili

\footnotetext{
${ }^{8}$ Renault M., Incidances de la tehnologie su l' exploatation bankarie, Banque, Pariz, 1990.

${ }^{9}$ Član 235. stav 1. tačka 6. Zakon o obligacionim odnosima (SI. List SFRJ br. 29/78 i dr.) u daljem tekstu ZOO.

${ }^{10}$ Rutzel H.K., Automation in the sistem of securities transfers, Frankfurter Wertpapierborse, Frankfurt/M, 1989.
} 
za obe strane, jasno je da manjkavost forme bude dovoljan razlog da pravnog posla nema ako ta forma nije poštovana od one (ili obe) koja je dužna da se u takvoj formi izjasni. Kod jednostrane izjave volje je ovo uočljivije, jer se obaveznost forme može odnositi samo i uvek na jednu stranu, tj. na onu od čije izjave zavisi nastanak obligacije. Sledstveni zaključak o tome kakve su posledice nedostatka odobrenja, kada je on naravno nužan, pri izdavanju hartija od vrednosti, je evidentan i u zavisnosti od propisa koji takav institut za takve hartije uvodi, tj. da li se radi o saglasnosti koja je deo forme ili ne. Ako bi saglasnost dakle, bila deo obavezne forme, razumljivo je da bez nje, uprkos ostalim ispunjenim formalnim uslovima, nema ni hartije od vrednosti.

Stanovište, po kojem se saglasnost za zaključenje ugovora smatra samo odložnim uslovom, ${ }^{11}$ ima za posledicu da ugovor bez takve saglasnosti ipak postoji, ali njegova punovažnost je odložena dok se saglasnost ne da, odnosno, ugovor ne bi nikada mogao postati punovažan (nastati) ako takva saglasnost potpuno izostane.

Identično dejstvo takvog stanovišta je nastanak obligacija jednostranom izjavom volje, jer se ovde saglasnost daje tako izraženoj jednostranoj izjavi. Tako je i u užem smislu, kada se radi o hartijama od vrednosti, iz čega bi proizlazilo da i kod takvih hartija, saglasnost predstavlja ne formu već formalnost sličnu formi.

Ako se pođe od toga da saglasnost, bilo u obliku dozvole ili u obliku odobrenja, predstavlja sastavni deo izjave volje, imali bi treću varijantu koja objašnjava pravnu prirodu takve ustanove, koja bi dakle, izražena kao menljivost volje, u stvari sprečavala nastanak pravnog posla. Ovakvo stanovište bi po svom dejstvu bilo isto kao kada se radi o saglasnosti kao sastavnom delu forme kod ugovora odnosno kod jednostrane izjave volje, jer bi sprečavalo nastanak obligacionog odnosa. Ako je, prema tome, odobrenje odnosno saglasnost sa voljom jedinstven akt i pored toga što ga daju različita lica, koja tek zajedno i saglasno daju relevantnu izjavu volje, tada bi obaveznost forme obuhvatila obe radnje koje imaju na stvaranje obligacionog odnosa jedinstveni konstitutivni efekat.

Mišljenja smo da potpunije razmatranje pitanja odobrenja sa teorijskog stanovišta u ovom slučaju ne bi imalo svoje opravdanje. Ovo iz razloga što, po našem mišljenju, uticaj na opšta shvatanja zavisi od konkretnih slučajeva, odnosno prihvaćenih rešenja u zakonodavnoj praksi. Prema tome, tek tako konkretno rešenje ukazuje na to da li se radi o saglasnosti koja predstavlja konstitutivni deo obavezne forme ili o formalnosti koja je formi slična. Stoga bi se u daljem izlaganju samo detaljnije osvrnuli na to kako je naš zakonodavac u pozitivnom pravu rešio pitanje saglasnosti posebnim osvrtom kod hartija od vrednosti.

Naš ZOO terminološki i pojmovno kod saglasnosti, razlikuje odobrenje i dozvolu. Dozvola se definiše kao „potrebna saglasnost trećeg lica“ koja se daje posle zaključenja ugovora, dok je odobrenje saglasnost koja se daje od trećeg lica pre zaključenja ugovora. Dakle, u zavisnosti da li se saglasnost daje pre ili nakon zaključenja ugovora, imamo odobrenje odnosno institut dozvole. Isti Zakon, nalaže istovremeno da, kako dozvola, tako i odobrenje, „moraju biti dati u obliku propisanom za ugovore za čije se zaključenje

\footnotetext{
${ }^{11}$ „Uslov jeste neizvesna činjenica od kojeg nastaje ili prestaje dejstvo nekog ugovora. Odloženi uslov deluje na ugovor od trenutka njegovog zaključenja - osim ako iz zakona ili prirode posla ili volje strana ne proističe nešto drugo" (čl. 74. st. 1. i 2. ZOO).

„Kad je za zaključenje ugovora potrebna saglasnost trećeg lica, ova saglasnost može biti data pre zaključenja ugovora, kao dozvola, ili posle njegovog zaključenja, kao odobrenje, ako zakonom nije propisano šta drugo" st. 1. čl. 29. ZOO.
} 
daju“. ${ }^{12}$ Sve ove odredbe, bez posebnog komentara i rezervi, možemo primeniti i za slučajeve jednostrane izjave volje uz razumljive specifičnosti koje se u pozitivnom zakonodavstvu predviđaju kada se radi o hartijama od vrednosti.

Međutim, ne samo kada se radi o razmatranju odobrenja kao instituta formalnosti sličnoj formi, već i u drugim slučajevima kod hartija od vrednosti, moramo imati u vidu njihovu raznovrsnost. Institut odobrenja kod hartija od vrednosti nameće, pored ostalog njihovu podelu na kratkoročne i dugoročne. Ovo svakako moramo imati u vidu zbog toga što dugoročne, odnosno pojedine kratkoročne hartije, u pogledu odobrenja imaju odvojen pravni režim. Naime, pravni režim odobrenja odnosi se samo na dugoročne hartije od vrednosti ${ }^{13}$, akcije i one hartije koje glase na stranu valutu. Kratkoročne hartije od vrednosti (ček, menica, udeli...) ne podležu režimu odobrenja, Zakonom o tržištu kapitala ${ }^{14}$ ulazimo u detaljniju problematiku režima odobrenja dugoročnih hartija od vrednosti i organa koji takvo odobrenje daje, kao i sankcije koje se predviđaju za nepoštovanje Zakona koje se na ovo odobrenje odnosi, iz čega izvlačimo i zaključak o pravnoj prirodi ovakvog odobrenja u našem pravu.

Zakon o tržištu kapitala propisuje poseban pravni režim nadležnog državnog organa koji obezbeđuje kvalitet hartija od vrednosti, davanjem prethodne saglasnosti u vidu odobrenja za izdavanje hartija od vrednosti.

Kakav je, sa stanovišta obavezne forme hartija od vrednosti karakter odobrenja koji izdaje u formi rešenja navedeni nadležni državni organ?

Odobrenje u konkretnom slučaju je rezultat upravnog postupka okončanog rešenjem koje se javno objavljuje. Konačno je i protiv njega se može voditi upravni spor. Ovo sve upućuje na nesumnjiv zaključak da se radi o odobrenju za izdavanje dugoročnih hartija od vrednosti što se ne bi moglo kvalifikovati ni kao formalnost sličnoj formi, pa ni kao odložni uslov u smislu građanskog prava. Ovo je vidljivo iz sankcija koje za ovaj slučaj nisu predviđene na terenu građanskog prava, već samo kao kaznene mere. Izdavanje hartija od vrednosti pre dobijanja odobrenja, odnosno protivno dobijenom rešenju, predstavljao bi prestup.

$\mathrm{Na}$ osnovu iznetog, dakle, nema nikakve sumnje da u navedenom slučaju, odobrenje nadležnog organa o dopuštenosti izdavanja hartija od vrednosti, nema uticaja na njihovu valjanost, ukoliko naravno, takve hartije sadrže sve bitne sastojke i formu predviđenu zakonom, pa prema tome, takvo odobrenje, nije deo obavezne forme, nije odložen uslov, pa ni formalnost slična formi, ako bi pod tim pojmom obuhvatili samo takve ustanove 0 kojima je napred bilo reči.

Ovakva vrsta odobrenja u najširem smislu, dala bi za pravo onim shvatanjima koja njihovo definisanje i pravnu prirodu dovode u direktnu vezu sa propisom koji takvu formalnost sličnu formi u obliku dozvole uvodi. Pri tome je bez sumnje potrebno ne samo iz sankcije, već iz cilja propisa o saglasnosti, utvrđivati pravnu prirodu u suštini raznorodnog instituta kao što je to odobrenje.

\footnotetext{
${ }^{12}$ Čl. 29. ZOO. Druge odredbe istog Zakona preciziraju posledice uskraćivanja saglasnosti kod pravnog odnosa poslovno nesposobnog lica (čl. 55. i 56.), odbacuju prekoračenja ili ovlašćenja (čl. 87. i 88.), o ništavosti opštih uslova (čl. 143.), o odobrenju radnji poslovođe bez naloga (čl. 228.) i dr.

${ }^{13}$ Stanišić, N., Stefanović, N., \& Radojević, T. [2016]. Determinante cene duga u Republici Srbiji. Teme, 40(2), 869-882.

${ }^{14}$ Zakon o tržištu kapitala (SI. Glasnik RS br. 31/2011).
} 
Ovlašćenja nadležnog organa za hartije od vrednosti bez sumnje uključuju i formalno ispitivanje valjanosti takvih hartija od vrednosti, tj. da li one sadrže sve formalne i bitne sastojke, odnosno sve posebne uslove ako se izdaju u seriji. Međutim, iako to nije izričito rečeno, ovo ispitivanje postojanja formalnih uslova, u odnosu na mnogobrojnost drugih koje takav organ traži za svrhe izdavanja dozvole, a tiču se prvenstveno ekonomskih prilika, poslovanja i namene sredstava dobijenih emisijom dugoročnih hartija od vrednosti i dr., stavljeno je u drugi plan i očigledno ne može ničim uticati na zakonom ustanovljene propise $^{15}$ o formi koji, kada se tiču hartija od vrednosti bez razlike, traže materijalizovanu formu u obliku pismene isprave kao materijalnog nosioca prava iz takvih hartija. Ni više ni manje od toga po pitanju forme. ${ }^{16}$ Odatle smatramo ispravnim zaključak po kojem se, u okviru propisa u kojima se regulišu materijalno - pravna i procesna pitanja odobrenja za izdavanje hartija od vrednosti, ne može odlučivati o drugačijoj formi od one propisane Zakonom, već samo o formalnostima sličnoj formi.

Rezime ovakvog rezonovanja na terenu dematerijalizovanih hartija od vrednosti sastojao bi se u tome, da nadležni organ praktično ne ulazi u onaj sledstveni postupak trgovine hartijama od vrednosti, u kojoj se odražava problematika forme, odnosno opredeljenje emitenta da li će ili ne, u skladu sa zakonom, ove „hartije“ pustiti u promet u formi isprave ili se opredeliti za njen dematerijalizovani oblik u vidu evidencije, ukoliko to nije zakonom izričito zahtevano.

\section{Formalnosti publiciteta}

Razlikovanje formalnosti publiciteta od forme je uočljivo, ne svojim spoljnim oblikom akta, bilo na terenu ugovornog prava, bilo u oblasti obavezivanja jednostranom izjavom volje, već svrhom i pravnim dejstvom takvog publiciteta i sankcijom za njegovo neispunjavanje. Akt publiciteta, u načelu, ima za svrhu upoznavanje trećih lica radi zaštite njihovih imovinskih interesa, sa sadržinom akta u ugovornom pravu, sa potrebama državnog organa za različite svrhe (sigurnost saobraćaja i/ili statističke potrebe, potrebe obezbeđivanja eventualno propisanih okvira ugovornih odnosa, socijalnih ciljeva i dr.). Prema tome, formalnost publiciteta nije formalni uslov za nastanak pravnog odnosa koji nastaje izjavama volje. Znači da pravni odnos nastaje na način kako je to propisao zakon, ispunjavanjem uslova za nastanak obligacionog odnosa (konsensualno ili u odgovarajućoj formi), a nastanku odnosa propis dodaje i obavezu formalnosti publiciteta, koji u nekim slučajevima može da uslovi do ispunjavanja ove formalnosti, dejstvo obligacionog odnosa, kada se po našem mišljenju, približavamo ustanovi odložnog uslova.

Formalnost publiciteta se najčešće tehnički sprovodi upisom nastalog pravnog odnosa u posebne knjige koje imaju svojstvo javne evidencije. Ovakav princip formalnosti publiciteta, kada se radi o hartijama od vrednosti proveden je u našem pravu u delu koji se odnosi na vođenje registra izdatih odobrenja za dugoročne hartije od vrednosti i registar kratkoročnih hartija.

\footnotetext{
${ }^{15}$ Krstić, S. [2016]. Značaj institucije Centralne banke za nacionalnu ekonomiju. Oditor - časopis za Menadžment, finansije i pravo, 2(2), 18-26.

${ }^{16}$ Što naravno, ne znači da organ ne može iz drugih razloga uskratiti davanje svojeg odobrenja.
} 
Za propuštanje obaveza izdavaoca, nisu predviđene sankcije koje predviđa građansko, već kazneno pravo, pa se dakle, ovakva formalnost publiciteta po svojoj pravnoj prirodi može u potpunosti izjednačiti sa onom o kojoj je bilo reč u ustanovi saglasnosti kod hartija od vrednosti.

Formalnost publiciteta, ili bolje reći obaveza publiciteta, u ovom slučaju dakle, nema dodirne tačke sa obaveznom formom hartija od vrednosti, niti dematerijalizacija takvih hartija unosi bitnu promenu u ovom delu postupka njihove emisije.

\section{Formalnost upisa u registar}

Od formalnosti publiciteta u izloženom smislu treba razlikovati formalnost upisa u registar hartija od vrednosti na ime koje se vodi kod izdavaoca takvih hartija. Naime, pored pravila da se pravo iz hartija na ime prenosi cesijom ili, kada je to određeno posebnim zakonom i indosamentom. ${ }^{17}$

Da li se u ovakvom slučaju radi o formi u kojoj se izjava o prenosu hartija na ime vrši ili o delu takve forme koja ima konstitutivno dejstvo ili o običnoj formalnosti publiciteta?

Za razliku od hartija od vrednosti na donosioca, gde se pravo iz takve hartije prenosi jednostavnim postupkom predaje takve hartije novom poveriocu, pa se time pravo iz hartije i pravo na hartiju prenose istom i jednovremenom radnjom, kod hartija od vrednosti na ime je pravilo da se pravo iz takve hartije prenosi cesijom, što upućuje na zaključak o dvema odvojenim radnjama. Radnji kojom se stvara osnov za prenos i radnji kojom se predaje navedena hartija. Cesija je pravni osnov, a predaja izvršenje obaveze. Cesija se obavlja na način predviđen za takvu ustanovu obligacionog prava. ${ }^{18}$ Samo posebnim zakonom se može odrediti da se prenos navedenih hartija od vrednosti prenosi i putem indosamenta. $^{19}$

U oba slučaja međutim, prenos prava iz hartije od vrednosti na ime mora se izvršiti zabeleškom na samoj hartiji i upisom prenosa u registar ako ga izdavalac vodi.

Iz izloženog možemo da zaključimo dve stvari. Prva je da se prenos prava iz hartije od vrednosti na ime vrši u formi koju pozitivno pravo predviđa za ugovor o cesiji, odnosno za prenos prava iz hartije, prema pravilima o indosamentu kada je takva mogućnost predviđena posebnom zakonom. Drugo je, da se prenos prava iz takvih hartija mora ubeležiti na samoj hartiji i upisati u registar kada se kao takav vodi kod izdavaoca.

U svim prethodnim slučajevima proučavanja obavezne forme kod hartija od vrednosti, imali smo razmatranje pitanja koja se tiču izdavanja takvih hartija kao izvora prava jednostranom izjavom volje.

Kod hartija od vrednosti na ime, susrećemo se i sa pitanjima forme prenosa hartija, odnosno prava iz takve hartije i forme kojem se hartije na donosioca prenose, ne zato što to pitanje kod ovakvih hartije ne postoji, već što je ono pravno-tehičkim rešenjem deformalizovano.

\footnotetext{
${ }^{17}$ Član 242. st. 3. ZOO.

${ }^{18}$ Revell J.R.C., Le conseguenze dei transferimenti eletronici di fondi, II risparmio, Milano, 1982.

${ }^{19}$ Richard H., Bols H., Resource - Based Accounting and Output - Budgeting as Common Patterns of Public Sector Financial Management Reforms, Baden - Baden, 2001.
} 
Ovakav složeniji i formalno obavezujući postupak kod hartija od vrednosti na ime, se opravdava posebnim razlozima veće sigurnosti prometa, ali ima svoje nedostatke u formalnostima koje otežavaju takav promet.

Sa druge strane, materijalnopravne posledice razlike u osnovu prenosa su značajne i uočljive jer, kod hartija od vrednosti na ime, mora se poštovati složenija procedura, uključujući pri tome i obaveznost forme kojom se postupak prenosa obavlja zbog toga što bi, u protivnim, taj prenos izostao ili bio manjkav. Ograničavajući se ovde za naše potrebe samo pitanjem upisa prenosa u registar hartija od vrednosti koji se vodi kod izdavaoca, pokušaćemo da odgovorimo na pitanje da li se u ovom slučaju radi o formi, formalnosti sličnoj formi ili nečem drugom.

ZOO određuje dva osnova po kojima se hartija od vrednosti na ime može prenositi na treće lice. To su cesija, a posebnim zakonom taj prenos se može predvideti i indosamentom. Međutim, zakon nalaže da se na samoj hartiji vidi osnov prenosa, pa određuje i kako se to vrši. ${ }^{20}$ Drugim rečima, zakon određuje posebna tehnička pravila koja se moraju poštovati da bi se prenos, bilo cesijom bilo indosamentom, na hartiji od vrednosti na ime evidentirao, pri čemu se dodatna evidencija ove vrste, u zavisnosti od želje izdavaoca, može predvideti i upisom prenosa u poseban registar koji bi vodio emitent. O značaju ovog upisa trebalo bi poći ocenom značaja upisa na samoj hartiji. Naime, prenos cesijom hartije od vrednosti na ime obavlja se u formi i na način kojim je ustanova cesije u našem pozitivnom pravu regulisana. Ona proizvodi pravno dejstvo između strana ugovornica zaključenjem ugovora o cesiji, ali dejstvo prema dužniku odnosno izdavaocu takve hartije, nastupa od trenutka kada je on o promeni poverioca obavešten. Prema tome, obaveštavanje izdavaoca navedenih hartija, kako u slučajevima cediranja tako i u slučajevima prenosa indosamentom, ima isti pravni učinak za izdavaoca, a to je ispunjenje obaveze iz takve hartije onom imaocu koji je takvo pravo stekao cesijom ili indosamentom, ali obavezno upisanim na način kako to predviđa zakon, i, prema opredeljenju izdavaoca ali sada i kao njegova obaveza, upis u vlastiti registar takvih hartija. Iz ovakvih razmišljanja, proizišao bi i zaključak da se formalnost upisa u registar ne bi mogla smatrati, ne samo kao obavezna forma ili njen deo od koje zavisi pravovaljanost prenosa hartije od vrednosti na ime, već ni kao formalnost slična formi koja je uvek obaveza koja se ispunjava prema trećem. U ovom slučaju to je vlastita obaveza emitenta koju je on, prema vlastitom izboru ustanovio, ali iz takvog izbora ta obaveza postoji i treba je ispuniti.

Da li dematerijalizacija hartija od vrednosti utiče na tehnologiju upisa ili njegov pravni značaj kod emitenta?

Obzirom da se ovo pitanje postavlja samo kod hartija od vrednosti na ime a, kod njihove dematerijalizovane varijante radi se o registrovanju (računima) kod kvalifikovanog posrednika, nema nikakve smetnje da emitent takođe (ako to želi) vodi svoj registar svojih poverilaca, koje mu posrednik redovno dostavlja. Takav upis, s obzirom na izloženo kod hartija od vrednosti, ima značaj samo vlastite potrebe, saznanja o poveriocima, a koju svrhu može emitent ostvariti i pribavljanjem odgovarajućeg izvoda iz evidencije, ali koji je sada istovremeno i relevantan sa stanovišta pravnog režima dematerijalizovanih „isprava“ ove vrste.

Kada se radi o metodološkom pristupu izučavanja pravnih posledica na pravni režim hartija od vrednosti i povratnog uticaja na tehnologiju prometa dematerijalizovanih isprava, po mišljenju autora najpre se moralo poći od razloga po kojima bi se moglo zaključiti

\footnotetext{
${ }^{20}$ Član 242. st. 3. ZOO.
} 
da je početna hipoteza o mogućnosti dematerijalizacije hartija od vrednosti ispravna i koji su razlozi koji taj zaključak opravdavaju.

Protivan zaključak, tj. da dematerijalizacija navedenih hartija nije moguća, onemogućio bi izvesno svako dalje raspravljanje o posledicama takvog eventualnog opredeljenja. Ali, kako to nije slučaj, sledstveno je nužno detaljnije objasniti posledične reperkusije na funkcionisanje takvog sistema u kojem nema više materijalnog nosioca tj. inkorporisanog prava u takvim ispravama. Metodološki pristup ovom problemu značajan je sa stanovišta objašnjenja geneze nastanka sistema dematerijalizacije i uslova kojom se dematerijalizacija isprava dešava. To su u prvom redu uslovi da hartije od vrednosti steknu potreban nivo zamenljivosti, pri čemu se neminovno ovaj fenomen upoređuje sa poslovanjem novcem na tekućim računima nosioca platnog prometa i načelima skripturalne tehnike.

\section{Zaključak}

Kod nevažnosti u oblasti ugovornog prava, nalazimo na karakterističnu postepenost sankcija u zavisnosti od različitosti uzroka koji su doveli do nevažnosti (ugovora). Od onih krajnje oštrih koji su uzrok potpune ništavosti, do onih slabijeg intenziteta koji relativiziraju ovakvu ništavost. Naš ZOO predviđa kod instituta nevažnosti (ugovora) one ništave i rušljive. Ništavost od početka utiče na valjanost pravnog posla, a ovi drugi tu ništavost relativiziraju (ne)postojanjem uslova za rušljivost (poništenje). Sasvim je razumljivo i izvesno da ove relativizacije kod hartija od vrednosti nema i ne može biti. Štaviše, ovde ne bi mogli sasvim da shodno primenimo kao podlogu za naše zaključke ustanovu nevažnosti ugovora iz dela ugovornog prava. Ovde bi, najpribližnije odgovarala ona teorijska konstrukcija koja je u podelu nevažnosti ugovora na ništave i rušljive unosila i one nepostojeće. Stoga bi i naš zaključak bio da bi kod hartija od vrednosti izostanak predviđene forme značio da takva pravna kvalifikacija ne postoji i nije nikada ni prividno nastala. Slično situacijama u ugovornom pravu kada su, kako kod ništavnih, tako i kod ugovornih slučajeva postojali oni uslovi za njihov nastanak, ali iz „nekog uzroka koji je postojao u trenutku zaključenja“ oni nisu punovažni, a dok kod strogo formalnih, upravo zbog nepoštovanja te forme, ne možemo govoriti o nevažnosti već o njihovom nepostojanju. Ako smo nedvosmisleno formu kod hartija od vrednosti kvalifikovali kao bitnu (,,ad solemmitatem“), tada takvih hartija kao rezultata u toj formi date jednostrane izjave volje nema (ne postoji). Time otpada svaka diskusija i razmišljanje o mogućim intenzitetima sankcija prema nepostojećim hartijama od vrednosti koja je uvek, u ovakvim slučajevima jedina i apsolutna, da takvih hartija nema. Možemo stoga na osnovu iznetog uočiti da u stepenovanju pravne veze i intenziteta sankcije zbog nepoštovanja forme u ugovornom pravu i kod hartija od vrednosti, postoji bitna razlika. Kod ovih poslednjih usled nepoštovanja forme, takve hartije (pravni odnos iz takvih hartija) ne postoji.

\section{Literatura}

[1] Перовић С., Формални уговори у грађанском праву, Београд, 1964. стр. 63.

[2] Renault M., Incidances de la tehnologie su l' exploatation bankarie, Banque, Pariz, 1990.

[3] Đukić, A. [2017]. Krađa identiteta - oblici, karakteristike i rasprostranjenost. Vojno delo, 69(3), 99-118. 
[4] Krstić, S. (2016). Značaj institucije Centralne banke za nacionalnu ekonomiju. Oditor - časopis za Menadžment, finansije i pravo, 2(2), 18-26.

[5] Krstić, S. L., Gligić-Savić, A. P., \& Gligić-Dumonjić, J. P. [2017]. Mogućnost upravljanja rizikom portfolija hartija od vrednosti. Vojno delo, 69(6), 374-383.

[6] Закон о тржишту капитала (Сл. Гласник РС бр. 31/2011)

[7] Закон о облигационим односима (Сл. Лист СФРЈ бр. 29/78 и др.)

[8] Radosavljević, M. (2018). Javni dug sa aspekta finansiranja Vojske Srbije. Oditor - časopis za Menadžment, finansije i pravo, 4(2), 48-57.

[9] Revell J. R.C., Le conseguenze dei transferimenti eletronici di fondi, II risparmio, Milano, 1982.

[10] Richard H., Bols H., Resource - Based Accounting and Output - Budgeting as Common Patterns of Public Sector Financial Management Reforms, Baden - Baden, 2001.

[11] Rutzel H. K., Automation in the sistem of securities transfers, Frankfurter Wertpapierborse, Frankfurt/M, 1989

[12] Salma, J. (2012). Notarijalno obligaciono pravo - načela javno-beležničkog prava, javnobeležnička forma i odgovornost javnih beležnika prema pravu Republike Srbije. Zbornik radova Pravnog fakulteta, Novi Sad, 46(1), 87-100.

[13] Stanišić, N., Stefanović, N., \& Radojević, T. (2016). Determinante cene duga u Republici Srbiji. Teme, 40(2), 869-882. 